Case Report

\title{
Sources, Sites and Components of Greenhouse Gases (GHGs) from Animal Agriculture in West Papua Province, Indonesia
}

\author{
Deny A. Iyai ${ }^{1, ~ *}$, Yubelince Y. Runtuboi ${ }^{2}$ \\ ${ }^{1}$ Departmentof Animal Production, Faculty of Animal Sciences, the State University of Papua, Jl. Gunung Salju, Amban. Manokwari, Papua \\ Barat \\ ${ }^{2}$ Department of Forest Conservancy, Faculty of Forestry, Papua University, Jl. Gunung Salju, Amban. Manokwari, Papua Barat
}

Email address:

da.iyai@yahoo.com (D. A. Iyai)

${ }^{*}$ Corresponding author

\section{To cite this article:}

Deny A. Iyai, Yubelince Y. Runtuboi. Sources, Sites and Components of Greenhouse Gases (GHGs) from Animal Agriculture in West Papua Province, Indonesia. International Journal of Environmental Monitoring and Analysis. Vol. 4, No. 5, 2016, pp. 121-126.

doi: 10.11648/j.ijema.20160405.11

Received: July 22, 2016; Accepted: August 5, 2016; Published: September 2, 2016

\begin{abstract}
Environmental status of an area needs to be recognized with both locally and globally measureable indicators. Papua Barat has played important roles as carbon sink of the world with its forest cover. However, recently many areas are being converted for several functions. Agricultural function is a leading sector for the environmental degradation with emissions uncounted produced. Data collected from nine regencies compiled by West Papua province environmental department were accounted for. Quantifications were made to compute average emission resulted from large livestock, small livestock and poultry-manure production. Manure and slurry were the main sources of GHGs emissions, i.e. $\mathrm{CO}_{2}, \mathrm{CH}_{4}$ and $\mathrm{N}_{2} \mathrm{O}$. The highest contribution was produced by poultry followed by large livestock and small livestock $(p<0.01)$. In terms of poultry, broiler was the highest $(\mathrm{p}<0.05)$ compared to village chicken, egg poultry and duck. The three highest producing emissions are Manokwari, Kota Sorong and Sorong.
\end{abstract}

Keywords: Manure, Greenhouse Gases, Methane, West Papua

\section{Introduction}

In the late two decades, greenhouse gases have been reported and questioned worldwide increasing the heat resulted in ozone depletion. Many factors had been identified causing this environmental phenomenon. Man-made products in such fields like agricultural field [3], fabrication and cars, are computed contributing on accumulated greenhouse gases (GHGs) in the ozone layer. These effects, such as acid rain and shifted local climate, are in turn resulted and experienced nowadays by many countries.

In country such us Indonesia, tropical rain forest is reduced significantly for various functions. Many forests cut and land converted to various functions such as infrastructure, buildings and agriculture productions. Although there has been shifted, by the low and regulation of department of Forestry, Republic of Indonesia), in forest production and management, damaged forests in many hectares have been occurred. Tropical forest owned by Indonesia mentioned as one of the world green belt left beside Brazil with its Amazon and Zaire, Africa. The latter has been increased in use in West Papua. Oil palm plantation and land for other agricultural production, such as housed and un-housed raising livestock, have been demanded [2]. This may give positive impact on losing carbon sink and carbon sequestration in the nature. Land use conversion in West Papua has drastically changed for some agricultural functions, such as paddy field and palm plantation. Due to this, emissions resulted towards $\mathrm{CH}_{4}$ and 
$\mathrm{N}_{2} \mathrm{O}-\mathrm{N}$ are exist [7]. In Papua particularly due to abundant land, livestock and poultry are established to increase net income of farmers. Positive effects of increasing animal population are meat adequate need for animal protein, income generation, social-cultural function and negative effects contributed are greenhouse gases depleted in the ozone $\left(\mathrm{O}_{3}\right)$.

Emissions are classified into so-called environmental impact categories (EIC), such as global warming, acidification, ozone depletion, and eutrhophication [11]. Global warming has potential effect globally compared to other EICs.Hence, local environmental impacts are risk for local population. The gases produced as global warming are carbon dioxide $\left(\mathrm{CO}_{2}\right)$, methane $\left(\mathrm{CH}_{4}\right)$ and nitrous oxide $\left(\mathrm{N}_{2} \mathrm{O}\right)$ [3] and [14]. Population of livestock and other animal agricultures is calculated as a main source contributing to increasing number of greenhouse gases in the ozone [7]. GHGs emissions are globally and locally chemical components that change local and global environmental circumstances.

Many countries therefore seek means for reducing GHGs so that global and particularly local causes can be minimalized. However, knowing potential and real GHGs production resulted from animal agricultural in West Papua becomes the priority. This is therefore environmental province board had made a report reporting all development (planning) activities of this province so that thiscan be a direction for making regulations. This article was aimed for seeking the sources and production of greenhouse gases resulted and contributed to ozone depletion.

\section{Materials and Methods}

Data samples were taken from annual reports of environmental status year 2009 compiled by environmental board. Data compiled were resulted from regencies of West Papua province, i.e. FakFak, Kaimana, Kota Sorong, Manokwari, Sorong, Sorong Selatan, Raja Ampat, Teluk Bintuni and Teluk Wondama. Databases derived from animal agricultural population in the West Papua province, i.e. livestock (cattle) as large animal agriculture, small livestock, i.e. goat and pigs, and poultry, i.e. village chicken, egg chicken, broiler chicken and duck. We also assumed that manure is the source of green house gases and contributed to global warming potential (GWP).Cattle produce $5 \mathrm{~kg}$ of feces day ${ }^{-1}$ of manure (+slurry), goat and pigs produce $4.5 \mathrm{~kg}$ manure day $^{-1}$ and poultry produce $3 \mathrm{~kg}$ of manure day ${ }^{-1}$. In $10 \mathrm{~kg}$ of manure, there is $0.5 \mathrm{~kg}$ of methane $\left(\mathrm{CH}_{4}\right)$. Therefore, we converted $\mathrm{CH}_{4}$ into $\mathrm{CO}_{2}$ by dividing Constanta of 21 with manure production resulted from every animal agriculture. $\mathrm{N}_{2} \mathrm{O}$ was calculated using $1 \times \mathrm{CO}_{2}$ production with 310 of $\mathrm{N}_{2} \mathrm{O}$, i.e. $\mathrm{N}_{2} \mathrm{O}=1 \times \mathrm{CO}_{2}$ production $\times 310 \mathrm{~N}_{2} \mathrm{O}$.

Environmental board of West Papua in collaboration with regencies had gathered records of animal agriculture population. In every $10 \mathrm{~kg}$ of manure, it was calculated to yield $0.5 \mathrm{~kg}$ of methane $\left(\mathrm{CH}_{4}\right)$. Global warming potential is composed by chemical components of $\mathrm{CO}_{2}, \mathrm{CH}_{4}$, and $\mathrm{N}_{2} \mathrm{O}$. GWP is expressed in $\mathrm{kg} \mathrm{CO}_{2}$ equivalent. Different $\mathrm{CO}_{2}$ equivalent used for the main green house gases were for $1 \mathrm{CO}_{2}$,
$21 \mathrm{CH}_{4}$ and $310 \mathrm{~N}_{2} \mathrm{O}$ (Assuming a 100 years time horizon). One $\mathrm{kg}$ of $\mathrm{CH}_{4}$ has the same effect on global warming as $21 \mathrm{~kg}$ of $\mathrm{CO}_{2}$. Emission of GHGs was calculated using equation as follows; Emissionof GHGs $=\sum_{i} A i \times E F i$, where Emissions of GHGs are in terms of $\mathrm{CO}_{2}, \mathrm{CH}_{4}$ and $\mathrm{N}_{2} \mathrm{O}$. Ai is sum of product (yield) and Efi is factor or Constanta of product.

An analysis of one-way Anova [13] was used. Classification was based on the three characteristics consisted of big animal agriculture, small animal agriculture, i.e. goat and pigs, and poultry. Mathematical formula is $\mathrm{Y} i j=\mu+\alpha i+\varepsilon i j$, where $\mathrm{Y} i j$ is variable responses consisted ofanimal population, manure production, $\mathrm{CH}_{4}$ production, $\mathrm{CO}_{2}$ production and $\mathrm{N}_{2} \mathrm{O}$ production. The $\mu$ is overall mean, $\alpha i$ is effect of animal agriculture, i.e. livestock, small livestock and poultry and $\varepsilon i j$ is errors with normal distribution, $\mathrm{N}(0, \mathrm{I})$. We also analyzed contribution of various poultry contribution, i.e. village chicken, egg chicken, meat chicken and duck as effect. We assessed differences among individual types of animals by pairwise comparison with the post hoc test of Duncen. Levene's test $(\alpha=0.05)$ was used to test for homogeneity of variance. Due to normality distribution test of data, such as animal population, manure production and methane production, log linear (ln) was employed. Qualitative and quantitative data were entered in Excel database, 2003. Analysis of data using SPPS version 18.0.was used.

\section{Results and Discussions}

\subsection{Sources of Green House Gases}

Gases resulted from manure or by-product of animal agriculture are methane $\left(\mathrm{CH}_{4}\right)$, carbon dioxide $\left(\mathrm{CO}_{2}\right)$, Nitrogen $\left(\mathrm{N}_{2}\right)$, hydrogen $\left(\mathrm{H}_{2}\right)$, carbon monoxide $(\mathrm{CO})$, oxygen $\left(\mathrm{O}_{2}\right)$ and hydrogen sulfide $\left(\mathrm{H}_{2} \mathrm{~S}\right)$. Percentages in gas-bio are subsequently $54-70 \%, 27-45 \%, 3-5 \%, 1-0 \%, 0.1 \%, 0.1 \%$ and in small percentages [16].

Actually several leading experts and authors of emission sources had written. [14] listed all components of methane sources and classifying to be natural sources and anthropogenic sources. The main sources of green house gases were originated of animal agriculture production is our concern. By-product sources of animal agriculture are manure including slurry [9]. Feces of large livestock, small livestock and poultry consist of manure and slurry. Uncounted GHGs potential can indeed be resulted from microbial digestion, i.e. methane $\left(\mathrm{CH}_{4}\right)$. Methane $\left(\mathrm{CH}_{4}\right)$ is much produced from microbial metabolic processes. Gases released from animal agriculture produced much more useless energy. No human-made technologies are available to collect combustion gases. [7] reported several potential sources of $\mathrm{CH}_{4}$, i.e. ruminant animals, animal wastes, rice paddies, and biomass burning and $\mathrm{N}_{2} \mathrm{O}$, i.e. mineral fertilizer, animal wastes, $\mathrm{N}$-fixation, biomass burning, soils after burning and forest conversion. Many literatures use $23 \times \mathrm{CO}_{2}$ for $\mathrm{CH}_{4}$ and 296 $\times \mathrm{CO}_{2}$ for $\mathrm{N}_{2} \mathrm{O}$. While $\mathrm{N} 2 \mathrm{O}-\mathrm{N}$ can be sourced from mineral fertilizer, animal wastes, $\mathrm{N}$-fixation, biomass burning, soils after burning and forest conversion which contributed around 4.2 $\mathrm{Tg} \mathrm{yr}^{-1}$. 


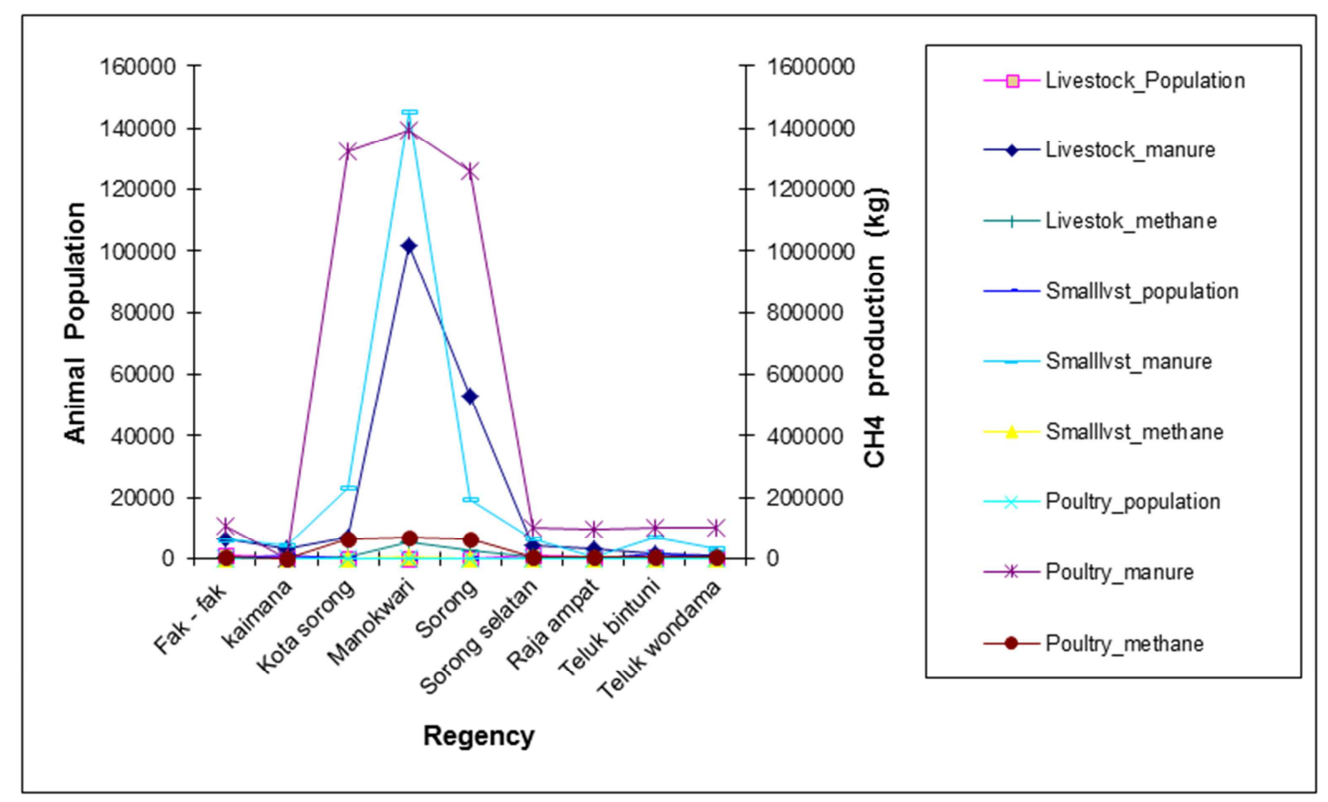

Figure 1.Number of animal population, manure production and methane production.

\subsection{Potential Sites Producing GHGs}

The three higher regencies-sources of animal agriculture population in West Papua were evidently produced by Manokwari followed subsequently by kota Sorong and Sorong (Figure 1.). However, if we add Sorong and kota Sorong, they become the main sources of methane, carbon dioxide and nitrate oxide in West Papua. They are the first three agricultural development in West Papua. The rest are the new regencies established under special autonomy regulation since year 2001. However, some of them are the so called new agricultural development potential in West Papua. Number of land available for agricultural land is $161.272 \mathrm{ha}$, consist of 11.975 ha of paddy field, 120.086 ha dry land and29.211 ha farm land [2].

Effects of methane on human were not stated clearly. Esthetical was the reason of people perception obtained during observation. It is lack of information with related to emissions emitted and effect on human life in West Papua. Odor was the output of livestock and poultry keeping in West Papua. However, perception of local community is unrecorded. So, what we suggested is that perception, values, attitude of farmers' neighbor or local community should be documented. Therefore, standard in determining environmental quality specific of this province is not made yet. Direction is still using Indonesian national standard (SNI). So far, no certain and strategic livestock and poultry areas are determined. There are several environmental analysis used in agricultural production, i.e. ecological footprint analysis/ecological footprints accounts (EFA) (Redefining Progress) and life cycle assessment (LCA) [11]. Further study is needed to draw strategic plans, constraints, how to tackle that constraints and so forth.

Table 1. Sources of greenhouse gases (GHGs) from livestock, Small livestock and poultry.

\begin{tabular}{|c|c|c|c|c|c|c|c|c|c|}
\hline \multirow{3}{*}{ Cummulative } & \multicolumn{6}{|c|}{ Animal Agriculture } & \multirow{2}{*}{\multicolumn{2}{|c|}{ Total $(n=27)$}} & \multirow{3}{*}{ Sig. } \\
\hline & \multicolumn{2}{|c|}{ Large Livestock $(\mathrm{n}=9)$} & \multicolumn{2}{|c|}{ Small livestock $(n=9)$} & \multicolumn{2}{|c|}{ Poultry $(n=9)$} & & & \\
\hline & Mean & SD & Mean & SD & Mean & SD & Mean & SD & \\
\hline Animal population & $4016.78 \mathrm{a}$ & 6931.54 & $5293.33 \mathrm{a}$ & 10247.84 & $166245.44 b$ & 207213.58 & 58518.52 & 138869.10 & 0.000 \\
\hline Manure (kg) & $20083.89 a$ & 34657.70 & $23820 \mathrm{a}$ & 46115.29 & $498736.33 b$ & 621640.73 & 180880.07 & 415197.95 & 0.001 \\
\hline $\mathrm{CH}_{4}(\mathrm{~kg})$ & $1004.19 \mathrm{a}$ & 1732.88 & 1191a & 2305.76 & $498736 b$ & 621640.73 & 166977.17 & 419589.09 & 0.000 \\
\hline $\mathrm{CO}_{2}(\mathrm{~kg})$ & 47.82 & 82.52 & 56.71 & 109.79 & 1187.46 & 1480.09 & 430.67 & 988.56 & 0.001 \\
\hline $\mathrm{N}_{2} \mathrm{O}(\mathrm{kg})$ & 14823.82 & 25580.68 & 17581.43 & 34037.48 & 368114.91 & 458830.06 & 133506.72 & 306455.63 & 0.001 \\
\hline
\end{tabular}

Superscript with different notation shown significant at $\mathrm{p}<0.01$.

Table 1 shows us that all data, animal population in every of the 9 regencies were differ significantly $(\mathrm{p}<0.01)$. This of course resulted in the number of manure produced, methane, carbon dioxide and nitrous oxide production. From quantified and computed data (as shown in Table 1), high increasing number of methane production was yielded by poultry $(498736.33 \pm 621640.73, \mathrm{p}<0.01)$ and subsequently followed by small livestock, i.e. pigs+goats which produced
$1191 \pm 2305.76 \mathrm{~kg}$ of methane emissions and large livestock, i.e. bali cattle which produced $1004.19 \pm 1732.88 \mathrm{~kg}$. In line with this, carbon dioxide produced was higher therefore in poultry $(1187.46 \pm 1480.09 \mathrm{~kg}, \mathrm{p}<0.01)$ and followed by small livestock and livestock. Total average $\mathrm{CH}_{4}, \mathrm{CO}_{2}$ and $\mathrm{N}_{2} \mathrm{O}$ produced was $166977.17 \pm 49589.09,430.67 \pm 988.56$, and $133506.72 \pm 306455.63$, respectively.

Despite growing livestock populations, global methane 
emissions from livestock remain static. One of the reasons for this is that monogastric production is growing faster pace than ruminant production. About $80 \%$ of the total growth of the livestock sector is attributed to pigs and poultry which emit comparatively small amount of methane. Any reduction in methane production, however, is likely to result increased emission of other gases, notably carbon-dioxide and nitrous oxide, as fossil fuels and fertilizer will be required in the intensification process.

These various database obtained from regencies determine precise number of population of animal agricultures kept by farmers. Providing a valid database in terms of housed and un-housed livestock, small livestock and poultry will easily determine further computation. Housed and un-housed animal will determine in term of manure and slurry management whether applied by farmers in their farm land, used as biogas and/or useless. Production of manure per se of animal in terms of physiological age also differs. Starter (day old chicken, DOC/day old duck, DOD), grower and adult poultry and/or livestock vary. [4] and [14] stated that contribution of ruminant on GHGs emission $84 \mathrm{Tg}^{-1}$. This should be divided to obtain valid quantification of GHGs beside taking into account several circumstances mentioned above.

So far it is known in Indonesia that only cattle and poultry manure have been applied as bio fertilizer and biogas. Manure resulted from pigs and goat is sometime avoided by farmers. Only in some regions of Indonesia, such as in Medan and East Nusa Tenggara, manure from pigs are collected and used as biogas. Cattle and dairy cattle (cow) produce $28 \mathrm{~kg}$ of manure day $^{-1}$, buffalo produce $35 \mathrm{~kg}$ of manure, goat produce $1.13 \mathrm{~kg}$ and pig produce $3.41 \mathrm{~kg}(= \pm 4.5 \mathrm{~kg})$ day $^{-1}$, village chicken $/$ race produce $0.18 \mathrm{~kg}$ of manure day ${ }^{-1}$, duck produce $0.34 \mathrm{~kg}$ of manure day ${ }^{-1}$ and man produce $0.15 \mathrm{~kg}$ of manure day $^{-1}$. Some agricultural animals are bred in outside Papua Barat, such as several Bali cattle breed, Etawa goat (recently introduced in Papua), meat poultry, egg poultry and duck. No breeding centers are available in Papua.

In terms of feeding, livestock feedssuch as concentrates and other commercial feed and ingredients are grown, processed and produced outside Papua. These activities need manufacturing involvements in processing such animal basic needs. This manufacturing needs energy, which is fossil fuel. Therefore this fossil fuel energy is released as residues of produced feeds. During transporting feeds and animal agriculture in Papua, ship and plane are used. Energy consumption in terms of producing one unit $(\mathrm{kg})$ of products should be calculated precisely. We therefore need to establish system analysis to limit our study based on the objective of research. Forages for livestock particularly cattle and goat are abundant. Forages in terms of grasses and legume with its technologies for reducing methane component are priority for further research in West Papua

\subsection{Poultry Population, Manure and Methan Production}

Data recomputed from 9 regencies (Figure 2.) resulted that Manokwari, kota Sorong and Sorong regencies were the three higher population of meat poultry kept by poultry farmers in West Papua.Number of meat poultry actually changeable every season and in line this the poultry population kept per farmer.Manure of poultry is not mostly utilizable. Only in small number of farmers, manure is applied as bio fertilizer.Meat poultry in Papua is demanded white meat for consumers compared to livestock and small livestock. Temporary growing population in West Papua has been stimulated real sector of agricultural field.

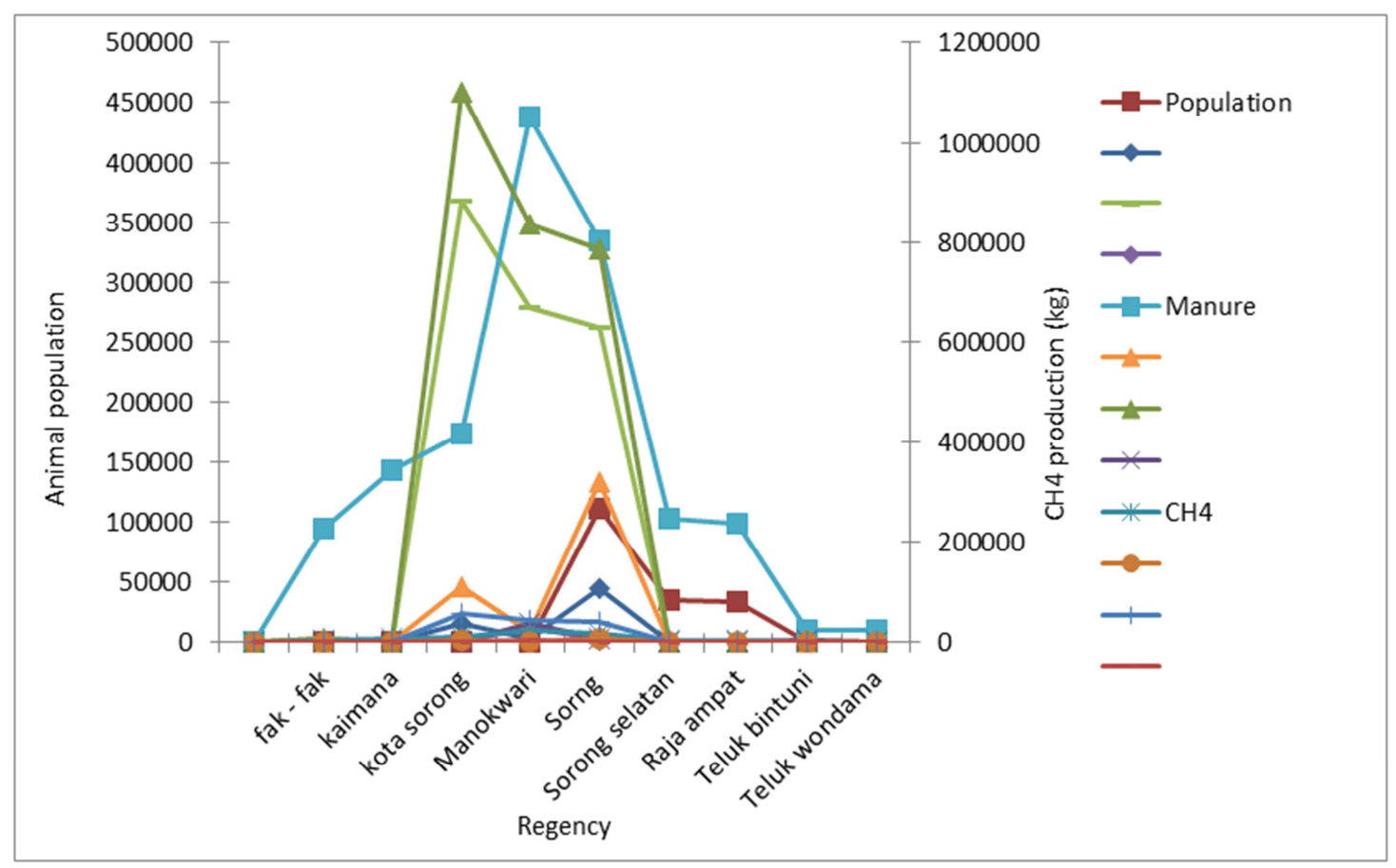

Figure 2. Poultry population, manure and CH4 production resulted in West Papua. 
Not only gases of emission were emitted, but also were several chemical components leached to the groundwater, surface water and soil. Data on groundwater pollution, surface water and soil are not studied yet.

Table 2. Sources of green house gases (GHGs) from poultry.

\begin{tabular}{|c|c|c|c|c|c|c|c|c|c|c|c|}
\hline \multirow{3}{*}{ Poultry } & \multicolumn{8}{|c|}{ Types of Poultry } & \multirow{2}{*}{\multicolumn{2}{|c|}{ - Total $(n=36)$}} & \multirow{3}{*}{ Sig. } \\
\hline & \multicolumn{2}{|c|}{ Village chicken $(n=9)$} & \multicolumn{2}{|c|}{ Egg Poultry $(n=9)$} & \multicolumn{2}{|c|}{ Meat poultry $(n=9)$} & \multicolumn{2}{|c|}{ Duck (n=9) } & & & \\
\hline & Mean & SD & Mean & SD & Mean & SD & Mean & SD & Mean & SD & \\
\hline $\begin{array}{l}\text { Animal } \\
\text { population }\end{array}$ & $51987.78 \mathrm{a}$ & 47728.15 & $6973.67 \mathrm{a}$ & 14954.41 & $3.3 \mathrm{~b}$ & 1.01 & $5 \mathrm{a}$ & 4.04 & 1.08 & 87388.35 & 0.047 \\
\hline Manure (kg) & $155963.33 \mathrm{a}$ & 143184.46 & 20921a & 44863.22 & $304090 \mathrm{~b}$ & 461133.05 & $5398.67 \mathrm{a}$ & 4084.04 & 121593.25 & 262165.08 & 0.047 \\
\hline $\mathrm{CH}_{4}(\mathrm{~kg})$ & $7798.17 \mathrm{a}$ & 7159.22 & $1046.05 \mathrm{a}$ & 2243.16 & $15204.50 \mathrm{~b}$ & 23056.65 & $269.93 \mathrm{a}$ & 612.61 & 6079.66 & 13.108 .25 & 0.047 \\
\hline $\mathrm{CO}_{2}(\mathrm{~kg})$ & $371.34 \mathrm{a}$ & 340.34 & $49.81 \mathrm{a}$ & $106.82 \mathrm{~b}$ & $724.02 b$ & 1097.93 & $12.85 \mathrm{a}$ & 29.17 & 289.51 & 104.03 & 0.047 \\
\hline $\mathrm{N}_{2} \mathrm{O}(\mathrm{kg})$ & $115115.79 a$ & 105683.77 & $15441.69 a$ & 33113.32 & $224447.38 \mathrm{~b}$ & 340360.11 & $3984.73 a$ & 9043.24 & 89747.39 & 193502.79 & 0.047 \\
\hline
\end{tabular}

$\mathrm{n}$ representing regencies. Superscript with different notation shown significant at $95 \%(\mathrm{p}<0.05)$.

Table 2 depicts that the higher average poultry population existing in West Papua was meat poultry $(101363.3 \pm 153722.01, \mathrm{p}<0.05)$. The rest subsequently were vary followed by village chicken, egg chicken and duck $(p<0.05)$. We cannot identify yet that means of poultry keeping kept by poultry farmers look like for instance battery cage (BC), deep litter (DL), deep litter with outdoor run (DLO) and aviary with outdoor run $(\mathrm{AO})$. We cannot identify that how many farmers with BC, DL, DLO and AO. The number of farmers is sometimes fluctuative and numbers of poultry that are kept also vary. Village chickens raised by local farmers were lagging behind sharing poultry market in Papua Barat. Meat chicken is still demanded of consumers in Papua. [11] is stated that global warming potential (GWP) is higher for DLO compared to BC. Besides, for acidification potential is higher for DL compared to DL and intermediate for $\mathrm{AO}$, due to higher ammonia emission from manure, present in the house, storage facility, or outdoor run. Eutrophication potential is highest for DLO and intermediate for DL and AO. This is due to the fact that DLO and DL had higher ammonia emission whereas systems with outdoor run had higher EP due to leaching from the manure in the outdoor run.

In database, several poultry data of regencies were not recorded. Therefore, the Bapedalda should organize gathering database.Field farming visits are needed to be explored to gain physical condition of livestockand poultry farming of every regency in terms of physiological age, feeding, farming systems.

\subsection{Gases Emissions of Livestock and Wastes}

Livestock are major sources of trace gases contributing to environmental at local to global scale, contributed about $80 \mathrm{Tg}$ $\mathrm{yr}^{-1}$ [7]. Ammonium volatilization can lead to nitrogen deposition, harming the natural ecosystem. In ruminant based systems, enteric fermentation and emissions from manure represent the bulk of emissions, whereas manure management and feed production represent the bulk of emissions associated with monogastric. Monogastric is non-ruminant animal agricultures such as pig and poultry.

There are two main sources of livestock-related carbon dioxide emissions related to climate change. First, carbon dioxide emissions resulted from biomass burning, part of which can be attributed to land clearing and bush fires for pasture and enhancing pasture growth. Second, carbon dioxide is released in relation to livestock-related consumption of fossil fuel for heating, manufacturing of machinery, and production of feed [9].

Methane gas is 23 times more aggressive in causing global climate change than carbon dioxide. Methane is the by-product of animal production and manure management, rice cultivation [12] and [10], production and distribution of oil and gas (pipelines), coal mining, and landfills [7]. Every year, livestock and manure management are estimated to emit 80 terra grams of methane, representing $25 \%$ of man-made sources. Methane is produced as a by-product of the feed digestion of mainly ruminant and, on average, about $6 \%$ of the feed energy is lost in methane [1]. Methane emission is the direct result of the capacity of ruminants to digest large amounts of fibrous grasses and other feeds which cannot be used for human consumption. Pigs and poultry cannot digest these fibrous feed and therefore emissions from these animals are relatively low.

Twenty percent of methane emanating from animal production comes from manure stored under anaerobic conditions. High levels of methane emissions from manure management are usually associated with high levels of productivity and intensity, as well as from large production units.

Nitrous oxide is the most aggressive greenhouse gas produced by livestock (296 times $\mathrm{CO}_{2}$ ). It is produced from animal manure. Every year livestock emit approximately 0.5 terra gram of nitrous oxide, representing $6 \%$ of man-made sources.

\subsection{Reducing Greenhouse Emissions}

We should inventory all emissions leaving the product system entering the surrounding environment, such as nitrous oxide $\left(\mathrm{N}_{2} \mathrm{O}\right)$, methane $\left(\mathrm{CH}_{4}\right)$, ammonia $\left(\mathrm{NH}_{3}\right)$, carbon dioxide $\left(\mathrm{CO}_{2}\right)$, nitrate $\left(\mathrm{NO}_{3}\right)$, phosphate $\left(\mathrm{P}_{2} \mathrm{O}_{5}\right)$ and pesticides leaching to the air, water or the soil. Emissions are classified into so-called environmental impact categories, such as global warming, acidification, ozone depletion, and eutrophication. Nitrous oxide $\left(\mathrm{N}_{2} \mathrm{O}\right)$, methane $\left(\mathrm{CH}_{4}\right)$, and carbon dioxide $\left(\mathrm{CO}_{2}\right)$ contribute to global warming potential (GWP). Eutrophication potential (EP) can be computed based on atrophying components, i.e. nitrate $\left(\mathrm{NO}_{3}{ }^{-}\right)$, nitrogen oxide 
$\left(\mathrm{NO}_{\mathrm{x}}\right)$, ammonia $\left(\mathrm{NH}_{3}\right)$ and phosphate $\left(\mathrm{PO}_{4}^{-}\right)$.Eutrophication potential has a strong local impact, and, therefore, generally expressed in $\mathrm{kg} \mathrm{NO}_{3}^{-}$equivalent $\mathrm{ha}^{-1}$ farm area and per $\mathrm{kg}$ product. Different $\mathrm{NO}_{3}{ }^{-}$equivalent used are 1 for $\mathrm{NO}_{3}{ }^{-}, 1.35$ for $\mathrm{NO}_{x}, 3.64$ for $\mathrm{NH}_{3}$ and 10.54 for $\mathrm{PO}_{4}^{-}$. Acidification potential (AP), as a local and global impact, generally is expressed in $\mathrm{kg} \mathrm{SO}_{2}$ equivalent $\mathrm{ha}^{-1}$ farm area and per $\mathrm{kg}$ product. Different $\mathrm{SO}_{2}$ equivalents used are 1 for $\mathrm{SO}_{2}, 0.7$ for $\mathrm{NO}_{x}$, and 1.88 for $\mathrm{NH}_{3}$.

Currently, the main policy constraint is the lack of appropriate incentives for the many existing technologies to reduce greenhouse emissions. The adoption of biogas technologies which convert methane from manure into energy is often hampered by the price of fossil fuels. In addition, there is still a lack of information on how to evaluate the benefits accruing from reducing the losses in the global common and on which mechanisms to use for distributing these benefits. Countries which have ratified Kyoto protocol have committed to reducing their greenhouse emissions, improving manure management seem to be the most cost-effective option, both in monogastric and ruminant based systems. Emissions from the various stages of manure management should be tackled animal house (periodicity of manure collection, building ventilation), storage (covering, temperature), processing (biogas production, and application/discharge (timing, mode of application).

\section{Conclusions}

Manokwari, kota Sorong and Sorong are the first three regencies contributed in GHGs. Poultry contributes in the highest GHGs emissions in West Papua followed by small-livestock and large livestock. Poultry production contributed GHGs emissions are meat poultry, village poultry, egg poultry and duck. It is suggested to identify other impact categories based on eutrophication potential, accidification potential resulted in West Papua.

\section{Acknowledgement}

We thank all parties of SKPD from nine regencies and one city of Sorong due to provided databases. Staffs of Bapedalda that made this article had possibility being published.

\section{References}

[1] Anonimous. 2005. Livestock-Environment Interaction. Briefing notes; production systems management. http://www.virtualcentre.org/selector.htm

[2] Bapedalda Papua Barat. 2009. Status lingkungan hidup daerah provinsi Papua Barat. Draft Final laporan.

[3] Cole, C. V., J. Duxbury, J. Freney, O. Heinemeyer, K. Minami, A. Mosier, K. Paustian, N. Rosenberg, N. Sampson, D. Saurbeck \& Q. Zhao. 1997. Global estimates of potential mitigation of greenhouse gas emissions by agriculture. Nutrient cycling in agroecosystems 49: 221-228.
[4] Denman, K. L., Chidthaisong, A., Ciais, P., Cox, P. M., Dickinson, R. E., Hauglustaine, D., Heinze, C., Holland, E., Jacob, D., Lohmann, U., Ramachandran, S., da Silvas Dias, P. L., Wofsy, S. C. and Zhang, X. 2007. 'Couplings between changes in the climate system and biochemistry', in S. Solomon, D. Qin, M. Manning, Z. Chen, M. Marquis, K. B. Averyt, M. Tignor and H. L. Miller (eds) Climate Change 2007: The Physical Science Basis, Cambridge University Press, Cambridge, pp 499-587.

[5] Gonzalez-avalos, E, \& L. G. Ruiz-Suarez. 2001. Methane emissions factors from cattle manure in Mexico. Bioresour. Technol. 80: 63-71.

[6] Hindrichsen, I. K., H. R. Wettstein, A. Machmuller, M. Keuzer. 2005. Methane emission, nutrient degradation and nutrient turnover in dairy cows and their slurry at different milk production scenarios with and without concentrate supplementation. Agriculture, Ecosystems and Environment 113: $150-161$.

[7] IPCC. 1996. Climate change (1995); Impacts, Adaptation and Mitigation of Climate Change. Scientific Technical analysis. Contribution of Working group II to the second assessment report of the intergovernmental panel on climate change. Watson RT, Zinyowera MC and Moss RH (eds) Cambridge University Press, New York.

[8] Jhonson, D. E., Johnson, K. A., Ward, G. M., Branine, M. E. 2000. Ruminants and other animals. In Khalil, M. A. K (Ed.), Atmospheric Methane: Its role in the global environmental. Springer-Verlag. Berlin, Germany, pp. 112-133.

[9] Johannson, D. E., Hill T. M., Ward G. M., Johannson K. A., Branine M. E., Carmen B. R. \& Lodman D.W. 1993. Ruminants and other animals. In: Khalil MAK (ed.) Atmospheric methane; sources, sinks, and role in Global Change, Springer-Verlag, NY, pp 199-299

[10] Lindau, C. W., Bollich P. K., DeLaune R. D., Mosier A. R. \& Bronson K. F. 1993. Methane mitigation in flooded Lousiama rice fields. Biol Fertil Soils 15: 174-178.

[11] Mollenhorst, H., P. B. M. Berenstein, I. M. J. de Boer. On-farm quantificaion of sustainability indicators; an implication to egg production systems. Submitted to British poultry science.

[12] Neue, H. U. 1992. Agronomic practices affecting methane fluxes from rice cultivation. In: Ojima DS and Svensson BH (ed). Ecol Bull, Copenhagen 42: 174-182.

[13] Ott, R. L. and M. Longnecker 2001. An introduction to statistical methods and data analysis. $5^{\text {th }}$ Edition. Texas A \& M University. Wadsworht Group USA.

[14] Reay, Dave, Pete Smith, and Andre van Amstel. 2010. Methane sources and the global methane budget. Dave Reay, Pete Smith and Andre van Amstel (Ed). Methane and Climate Change. Eathcan publishing for sustainable future. London. UK.

[15] Redefining Progress. Ecological footprints accounts: moving sustainability from concept to measureable goal. http://www.RedefiningProgress.org.

[16] Widarto, L \& Fx. Sudarto. 1997. Membuat Biogas. Teknologitepatguna. Kanisius. Yogyakarta. 